\title{
Experimental model of cultured skin graft $^{1}$
}

\author{
Alfredo Gragnani ${ }^{2}$ \\ Jeffrey R. Morgan ${ }^{3}$ \\ Lydia Masako Ferreira ${ }^{4}$
}

\begin{abstract}
Gragnani A, Morgan JR, Ferreira LM. Experimental model of cultured skin graft. Acta Cir Bras [serial online] 2004 Vol 19 Special Edition. Available on URL: http://www.scielo.br/acb.
\end{abstract}

\begin{abstract}
One of the most used animal models of cultured keratinocytes autografting is based on xenografting of human keratinocytes to the rat or athymic mice, immunological neutral recipient that acts as biological carrier. It could be studied in this model many facts that occur after transplant without the ethical aspect in the clinical study. The proposition of the experimental model is related to the sequence of the total or partial skin transplant, as autografting or xenografting, cultured or not, to the back of athymic mice. The model presents the possibility of study in vivo athymic animal, when the in vivo study in anima nobili is not ethical. It permits the xenografting evaluation of cultured cells graft or of the genetically modified cells and of the association of the cultured cells and the dermal substitutes, the composite grafts, and of the autografting.
\end{abstract}

KEY WORDS - Keratinocytes. Dermis. Skin transplantation. Cells, Cultured. Athymic mice.

\section{Introduction}

The possibility of using pure epidermal sheets or epithelial cell suspensions or associated with dermal analogues as grafts was first investigated in animal models over 40 years ago ${ }^{1}$. Thus, animal models for cultured keratinocyte grafting may now include autografts or allografts in many species. In addition, cultured human epithelial xenografts can be transplanted to immunodeficient athymic mice or rat as a model of human autografting.

The common used model of keratinocytes autografting involves production of epidermal cells graft dissociated that proliferating until the confluence in vitro and they are transplanted as sheets.

One of the most used animal models of cultured keratinocytes autografting is based on xenografting of human keratinocytes to the rat or athymic mice, immunological neutral recipient that acts as biological carrier. It could be studied in this model many facts that occur after transplant without the ethical aspect in the clinical study. 
Authors related the first observations of the use of cultured human keratinocytes sheets of the dissociated cells ${ }^{2}$, and now those are the cultured graft more common in the clinical use of this model $^{3}$. This model permits direct identification of graft from epidermal and the differentiation of the outer part proliferation of the native epidermis by immunohistochemical localization and keratinocyte specific antigen as involucrin. The disadvantages of this model are the limitations of the study time, because the grafts showed deterioration in 4 to 6 weeks and the wound contraction specific on this model ${ }^{2,3}$.

Three basic surgical techniques have been used in this model: 1.grafting onto the dorsal trunk muscle fascia (i.e. the panniculus carnosus muscle is excised with the skin), 2.grafting onto the panniculus carnosus, and 3. grafting onto the undersurface of an isolated dorsal skin flap. With either of the two techniques of grafting to full-thickness dorsal wounds, wound contracture and mouse epithelial ingrowth have been significant problems and silicone wound isolation chambers, used with success in normal animals, have proven difficult to implant in the delicate skin of athymic animals ${ }^{4}$.

Two technical solutions to this problem, both of which involved isolation of a dorsal skin flap and transplantation of cultured graft to the undersurface of the flap (connective tissue subjacent to the panniculus carnosus). By one technique, the flap is closed to protect the graft after a sheet of silastic is inserted between the graft and trunk musculature to prevent graft maceration. By this method, grafts are not exposed to air and cannot be examined without opening the flap. In a second technique, the flap is everted to expose its undersuface and sutured in place. Grafts are transplanted to the everted surface and protected from desiccation with wound dressings. By both techniques, cultured human epithelial sheets attach and differentiate as they would in a human wound, but grafts tend to deteriorate within 6-8 weeks or less.

A remarkably normal neodermis eventually regenerate from wound bed connective tissue subjacent to the cultured epithelial autografts, the process is lengthy ${ }^{5}$. Furthermore, pure epithelial grafts are often associated with significant wound contracture and epidermal fragility. Efforts to design a synthetic biological graft that more closely resembled normal skin containing both as epidermal and a dermal component determine the development of various kinds of composite grafts using a dermal equivalent or substrate to support the growth of keratinocytes ${ }^{6,7}$.

On such rigid supports, keratinocytes can be raised to the air-liquid interface of the culture medium and under these conditions, have been found to differentiate more normally than keratinocytes grown fully submerged in liquid, the conventional method of cultured epithelial graft preparation $^{8}$. Several investigators have shown that keratinocytes cultivated on dermal substrates generate a dermal-epidermal junction in vitro with the formation of basement membrane zone structures such as hemidesmosomes and basal lamina.

Therefore, this partial formation of the dermal-epidermal junction in the composite graft before transplanting can accelerate the stability after transplant, when compared to the cultured keratinocyte sheet graft, in which the structures of this junction should be produced completely after the transplant. This technique is a hard work and permits a important result compared to the sheets $^{6,9}$.

The model described is the transplant of the composed graft of the cultured keratinocytes and human acellular dermis in the fascia on the back of athymic mice ${ }^{10,11}$.

\section{Proposition}

The proposition of the experimental model is related to the sequence of the total or partial skin transplant, as autografting or xenografting, cultured or not, to the back of athymic mice.

Studies of such epithelia transplanted to wound bed connective tissue have produced important new insights into epithelial-connective tissue interactions and events in epidermal regeneration during wound healing. Such studies have generated important data on epithelial 
growth and differentiation in vivo and established the feasibility of current medical applications for keratinocyte grafts. Later efforts to produce cultured grafts that more closely resembled conventional skin grafts containing both epidermal and dermal layers have led to the development of composite cultured grafts.

With the development of keratinocyte autografting models, long-term studies of cultured autografts are now possible in animals. Questions about the biomechanical properties of skin regenerated from cultured keratinocyte grafts, the impact of in vitro cultivation, the epidermal aging, the proliferative capacity, and the pathological changes that might be associated with graftderived skin can all be studied in animal models under controlled conditions.

\section{Method description}

Grafting was performed in a horizontal laminar flow hood using 5-8 week old NIH Swiss nu/nu mice (Taconic Farms, Germantown, NY), anesthetized with an intraperitoneal injection of 2,2,2,-tribromoethanol (0,58 mg/g body weight) (Aldrich Milwaukee, WI).

The composite grafts constituted by human acellular dermis seeding with primary cultured keratinocytes and elevated to the air-liquid interface on the third day after seeding and on the tenth day the grafts are transplanted to the back of the mice ${ }^{10,12}$.

The dorsum of the mice was washed with 70\% ethanol and povidine (FIGURE 1).

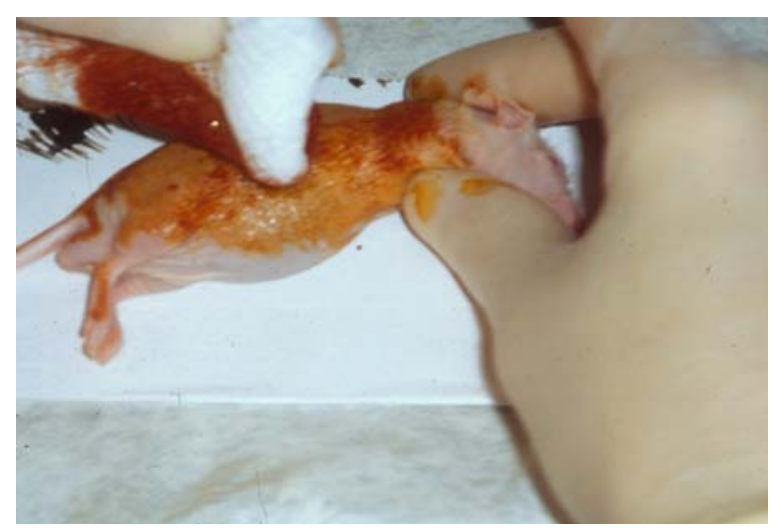

FIGURE 1 - Dorsum of the mice washed with povidine.

The right lateral area of the back of the mice is used as bed graft and is marked $0,5 \mathrm{~cm}$ from right frontal foot and $0,5 \mathrm{~cm}$. from medial dorsum line (cranial-caudal). The limits of the composite graft to be grafted are traced in a transparency film put above the tissue culture dish to facilitate the drawing of the graft onto the back of the mice and also can be stored to further evaluation to compare the initial size of the defect with the final size and determine the contraction of the grafted area.

The drawing is transposed to the receptor area on the back of the mice with marker pen with the same size. Scissors were used to create a full-thickness (including panniculus carnosus), $1,5 \mathrm{~cm}^{2}$ defect down to the fascia of the dorsal musculature, and it is avoided the bleeding, when it occurred, it solved with compression. 
The composite graft is removed from the tissue culture dish and placed on the wound, trimmed to fit precisely in the defect, and traced with transparent film. The graft is secured with a 60 nylon stitch at each corner (FIGURE 2).

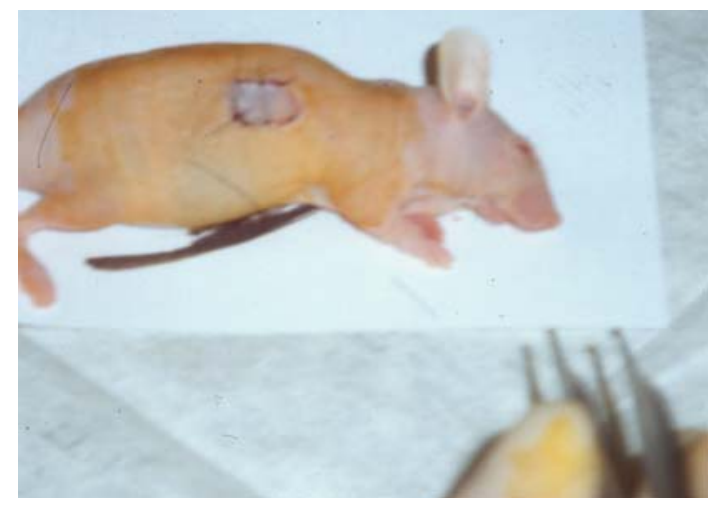

FIGURE 2 - Suture of the cultured composite graft onto the dorsum of the athymic mice.

Triple antibiotic ointment is applied to two stacked pieces of Telfa no-stick gauze (Kendall Co., Mansfield, MA) or rayon; the pieces are applied to the graft and secured with 6-0 nylon sutures.

A skin adhesive (Benzoin; Ferndale Lab, Ferndale, MI) is applied to the mouse skin around the wound, and one half of a 5 x 6,5 cm piece of Tegaderm brand polyurethane occlusive dressing (3-M, St. Paul, MN) is applied over the Telfa or rayon dressing (FIGURE 3).

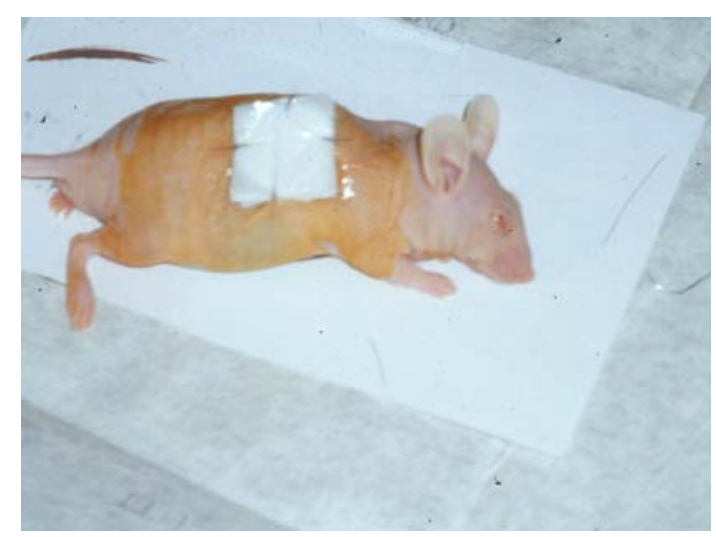

FIGURE 3 - Suture of two stacked pieces of Telfa ${ }^{\circledR}$ or rayon with triple antibiotic ointment over the cultured composite skin graft.

The graft also is dressed with a trimmed 3-M Sports Band-Aid ${ }^{\circledR}$, which is placed over the Tegaderm $^{\circledR}$, transversal to the cranial-caudal line (FIGURE 4). 


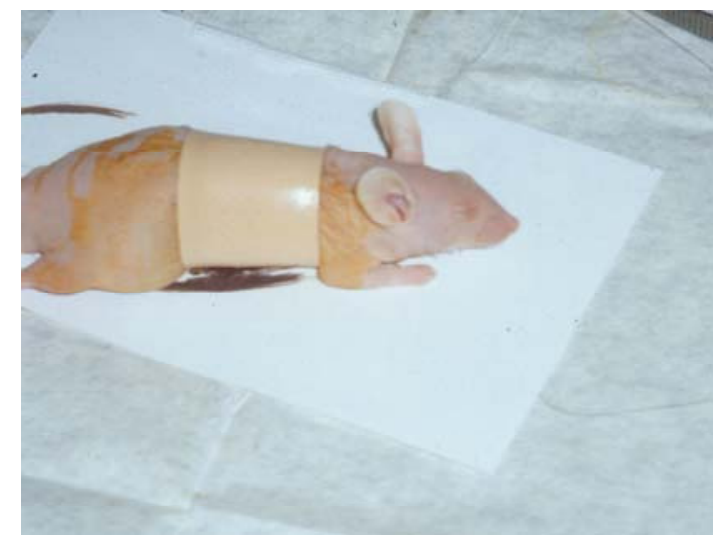

FIGURE 4 - Band-Aid $^{\circledR}$ over sutured dressing transversal to cranial-caudal line.

Finally, a $1 \mathrm{~cm}$ wide piece of waterproof adhesive tape (Johnson and Johnson, NJ) is wrapped around the mouse to cover circularly the dressing, from frontal foot until after $0,5 \mathrm{~cm}$. forward graft, to avoid the self-attack (FIGURE 5)

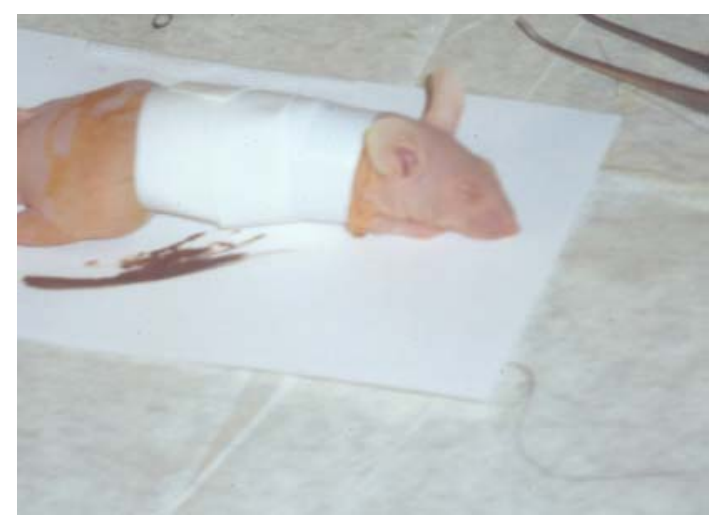

FIGURE 5 - $1 \mathrm{~cm}$ wide piece of waterproof adhesive tape wrapped around the mouse.

The evaluation of the bandages is realized daily. All bandages were changed at 4 days after the transplantation, and the grafts are submitted to a photographic documentation, the graft borders are traced in transparent film to evaluate the wound contraction.

The grafts are covered again with rayon or Telfa ${ }^{\circledR}$ with triple antibiotic ointment without sutures, Tegaderm ${ }^{\circledR}$ and waterproof adhesive tape. Finally let the graft without dressing at 7 days.

The procedure of the skin autografting is similar to the human cultured skin xenografting until the skin resection of dorsum of the mice, which is elevated in block with panniculus carnosus and it is excised from the graft base. The graft suffered an $180^{\circ}$ rotation and is sutured as above explained. The bandages and the post-surgery care are the same to the xenografting.

Each animal is maintained in an individual and sterilized cage, with sterilized water and food. The cleansing, the evaluations and bandages changes are made in a horizontal laminar flow hood. 
Experimental models of cultured keratinocytes grafts permit the opportunity of investigation of the skin regeneration biology and the interactions between matrices and epidermis during wound healing.

In contrast with human clinical studies, the animal models permit the study of the post-graft in small intervals without limitation of the quantity of the biopsy.

These models are ideals to the study of the epidermal growth and differentiation, of the epidermal and matrices citoquine expression, of the adhesion molecules expression intra and extracellular, of the regeneration of the components of the basement membrane zone, of the dendritics cells proliferation and of the repigmentation.

Animal models also permit the controlled study of the many involved aspects of the wound bed in the epidermal regeneration of the cultured keratinocytes graft. These aspects are difficult to control in clinical studies as bacterial colonization, antiseptic agents and topical antibiotics, and the wound granulation tissue maturation and graft angiogenesis.

They can be used to the development of new techniques to improve the clinical use and efficiency of keratinocytes graft. In particular situation, there is the wound bed preparation with dermal substitutes or dermal supports to the cells, topical application of the growth factors, the adhesion of the graft with biological glue and the wound bed preparation with laser.

With the keratinocytes autografting animal model are possible studies of long term under controlled conditions, evaluating biochemical properties of regenerated skin from cultured keratinocytes graft, the growth capacity of the cultured skin, the skin aging and the pathological alterations associated with the cultured skin.

Allografting model of cultured keratinocytes permit the rejection immunologic study. Besides the expected rejection on this kind of graft, allografting is clinically used as a biological dressing to improve healing.

\section{Perspectives}

The model presents the possibility of study in vivo athymic animal, when the in vivo study in anima nobili is not ethical. It permits the xenografting evaluation of cultured cells graft or of the genetically modified cells and of the association of the cultured cells and the dermal substitutes, the composite grafts, and of the autografting.

\section{References}

1. Billingham RE, Reynolds $\mathrm{J}$ - Transplantation studies on sheet of pure epidermal epithelium and of epidermal cell suspensions. Br J Plast. 1952; 23:25-36.

2. Banks-Schlegel S, Green H - Formation of epidermis by serially cultivated human epidermal cells transplanted as an epithelium to athymic mice. Transplantation. 1980;29(4):308-13.

3. Green, H - Cultured cells for the treatment of disease: The successful growth of human skin cells in culture has made it possible to restore epidermis after severe burns and other forms of damage. Sci Am. 1991 Nov; 96-102

4. Barrandon Y, Li V, Green H - New techniques for the grafting of cultured human epidermal cells onto athymic animals. J Invest Dermatol. 1988; 91(4):315-8.

5. Compton CC, Gill JM, Bradford DA, Regauer S, Gallico GG, O’Connor NE - Skin regenerated from cultured epithelial autografts on full-thickness burn wounds from 6 days to 5 years after grafting: A light, electron microscopic and immunohistochemical study. Lab Invest. 1989; 60(5):600-12.

6. Medalie DA, Tompkins RG, Morgan JR - Evaluation of acellular human dermis as a dermal analog in a composite skin graft. Asaio J. 1996; 42:1-8. 
7. Medalie DA, Eming SA Collins ME, Tompkins RG, Yarmush ML, Morgan JR - Differences in dermal analogs influence subsequent pigmentation, epidermal differentiation, basement membrane, and rete ridge formation of transplanted composite skin grafts. Transplantation. 1997; 64(3):454-65.

8. Ponec M, Weerheim A, Kempenaar J, Mulder A, Gooris GS, Bouwstra J, Mommaas AM - The formation of component barrier lipids in reconstructed human epidermis requires the presence of vitamin C. J Invest Dermatol. 1997; 109(3):348-55 .

9. Medalie DA, Eming,SA, Tompkins RG, Yarmush ML, Krueger GG, Morgan JF - Evaluation of human skin reconstituted from composite grafts of cultured keratinocytes and human acellular dermis transplanted to athymic mice. J Invest Dermatol. 1996; 107(1):121-7.

11.Sheridan RL, Morgan JR, Cusick JL, Petras LM, Lydon MM, Tompkins RG - Initial experience with a composite autologous skin substitute. Burns. 2001; 27(5):421-4

12.Gragnani A, Morgan JR, Ferreira LM - Experimental model of cultured keratinocytes. Acta Cir Bras. 2003; 18(especial):4-14.

13..Leigh IM, Lane EB, Watt FM - The Keratinocyte Handbook. $1^{\mathrm{a}}$. ed. Cambridge, University Press, 1994. 566p.

Gragnani A, Morgan JR, Ferreira LM. Modelo experimental de enxerto de pele cultivado. Acta Cir Bras [serial online] 2004 Vol 19 Edição Especial. Disponível em URL: http://www.scielo.br/acb.

RESUMO - Um dos modelos animais mais utilizados de auto-enxertia de queratinócitos cultivados é baseado em xeno-enxerto de queratinócitos humanos em rato atímico, um receptor imunologicamente neutro que atua como carreador biológico. Muitos fatos podem ser estudados nesse modelo que acontecem após o transplante sem os aspectos éticos do estudo clínico. A proposição do modelo experimental esta relacionada a sequência do transplante de pele parcial ou total como auto-enxerto ou xeno-enxerto, cultivado ou não, no dorso do rato atímico. O modelo apresenta a possibilidade do estudo in vivo do animal atímico, quando o estudo in vivo em anima nobili não é considerado ético. Isso permite a avaliação do xeno-enxerto de células humanas normais ou modificadas geneticamente modificadas cultivadas e a associação de células cultivadas e substitutes dérmicos, de enxertos compostos e de auto-enxerto.

DESCRITORES - Queratinócitos. Derme. Transplante de pele. Células cultivadas. Rato atímico.

Conflito de interesse: nenhum

Fonte de financiamento: CAPES

Correspondence:

Alfredo Gragnani

UNIFESP-EPM, Plastic Surgery Division, Surgery Division

Rua Napoleão de Barros, $715,4^{\circ}$ andar

CEP 04024-900 São Paulo - SP

Tel: (11) 5576.4118 Fax: (11) 5571.6579

sandra.dcir@epm.br

gragnani.dcir@epm.br 